\title{
Disease threshold for cherry leaf spot incidence on commercial sweet cherry cultivars
}

\author{
Varga, M., Vámos, A., Molnár B. \& Holb, I. J. \\ University of Debrecen, Faculty of the Agricultural and Food Sciences and Environmental Management, Institute of Horticulture, \\ University of Debrecen 138 Böszörményi St., 4032 Debrecen, Hungary \\ Author for correspondence: holbimre@gmail.com
}

\begin{abstract}
Summary: The aim of this study was to demonstrate the $10 \%$ threshold level for cherry leaf spot incidence on 23 commercial sweet cherry cultivars in two training systems. Twenty three cherry cultivars were evaluated in the two training systems with a spacing of $4 \mathrm{x} 1 \mathrm{~m}$ and with a spacing of $2 \mathrm{x}$ $5 \mathrm{~m}$. Results showed that leaves of many cultivars were heavily infected, e.g. cultivars (cvs) 'Biggareau Burlat', 'Sunburst', while others showed low disease incidence e.g. cvs 'Celeste' and 'Blaze Star'. According to the $10 \%$ threshold level, cv 'Celeste' proved to be the most resistant cultivar to leaf infection, while cv 'Münchebergi korai' exceeded extremely the $10 \%$ threshold level. Leaf spot incidence was affected by training system on most cultivars. Thirteen cultivars had less than $10 \%$ infection in the $4 \times 1 \mathrm{~m}$ spacing (i.e. they did not reach the $10 \%$ disease threshold level). At the same time, only 3 cultivars showed less than $10 \%$ infection in the $5 \times 2 \mathrm{~m}$ spacing.
\end{abstract}

Varga, M., Vámos, A., Molnár B., Holb, I. J. (2019): Disease threshold for cherry leaf spot incidence on commercial sweet cherry cultivars. International Journal of Horticultural Science 25(1-2): 52-54. https://doi.org/10.31421/IJHS/25/1-2/3139

Key words: cherry leaf spot, Blumeriella jaapii, disease threshold, cultivars

\section{Introduction}

There are some possibilities for assessing plant disease levels by precision agriculture techniques. It is known that remote sensing can be used to examine e.g. the plant diseases on leaves. Such a disease can be cherry leaf spot (Blumeriella jaapii) which significantly reduces yield of cherries (e.g. Kaszonyi, 1966; Pedersen \& Løschenkohl, 1997; Jenser \& Véghelyi, 2003; Holb \& Veisz, 2005; Király \& Szentpéteri, 2006; Holb, 2009; Holb et al., 2010, 2011, 2014; Vámos \& Holb, 2013). Blumeriella jaapii causes defoliation by the end summer and only poor quality fruit produced by the trees. The epidemics of cherry leaf spot can lead to full and early defoliation of the trees and can cause serious economic damage especially in rainy years. Due to early defoliation, tree conditions are weaken and only weak buds develop as well as frost sensitivity of the trees is also increased (Kaszonyi, 1966; Howell \& Stackhouse, 1973; Sjulin et al., 1989; Jenser \& Véghelyi, 2003; Holb \& Veisz, 2005; Borovinova et al., 2007, 2014; Holb, 2009; Proffer et al., 2013; Borovinova \& Petrova, 2015). The situation can be worse if plant protection does not reach the expected level. The disease development is also affected by training system and cultivars. However, threshold level of cherry leaf spot for the cherry cultivars is needed in order to successfully apply remote sensing options in integrated plant protection as part of the precision fruit technology.

Aim of our study was to present the $10 \%$ threshold level for cherry leaf spot incidence on 23 commercial sweet cherry cultivars in two training systems.

\section{Materials and methods}

The study was carried out in Debrecen (Pallag Experimental Station, Debrecen University) in a sweet cherry orchards planted where trees were planted in two training systems with a spacing of $4 \times 1 \mathrm{~m}$ and with a spacing of $2 \times 5 \mathrm{~m}$. Trees were grafted on Prunus mahaleb and were grown from the year of 2000. Twentythree sweet cherry cultivars (cvs) were evaluated: 'Celeste', 'Blaze Star', 'Vega', 'Szomolyai fekete', 'Rita', 'Cristallina', 'Katalin', 'Aida', 'Lapins', 'Izabella', 'Stella', 'Van', 'Germersdorfi 3', 'Krupnodlodnaja', 'Vera', 'Axel', 'Linda', 'Margit', 'Valerij Csaklov', 'Sunburst', 'Biggareau Burlat', 'Solymári gömbölyü' and 'Münchebergi korai'.

Eight fungicide applications were used against fungal diseases of sweet cherry according to the Integrated Fruit Protection guidelines. Copper hydroxide was used at dormant bud stage and then 6 additional sprays were applied during the season with the active ingredients of tebuconazole, pyraclostrobin, captan and dodine. The final spray was copper used in August.

Disease observation was prepared at the end of August. A minimum of four trees were observed and $4 \times 25$ leaves were assessed for disease. Percentage of cherry leaf spot was determined. Then a $10 \%$ threshold level of disease incidence was determined for each cultivar and for both training systems.

\section{Results and discussion}

All cherry cultivars were infected to a greater or lesser extent, but most infection was in the category of lower than $10 \%$ disease threshold level. Leaves of many cultivars were heavily infected, e.g. cvs 'Biggareau Burlat' and 'Sunburst', while 
others showed low infection of the pathogen e.g. cvs 'Celeste' and 'Blaze Star'.

According to the $10 \%$ threshold level, cv 'Celeste' proved to be the most resistant cultivar to leaf infection (Figure 1). The rate of leaf infection did not exceed $10 \%$, and the symptoms appeared mainly at the edge of the leaf. The cv 'Blaze Star' showed also a lower infection rate. The tolerant cultivar, 'Szomolyai fekete' was slightly diseased but only partially confirmed its tolerance known from the literature.

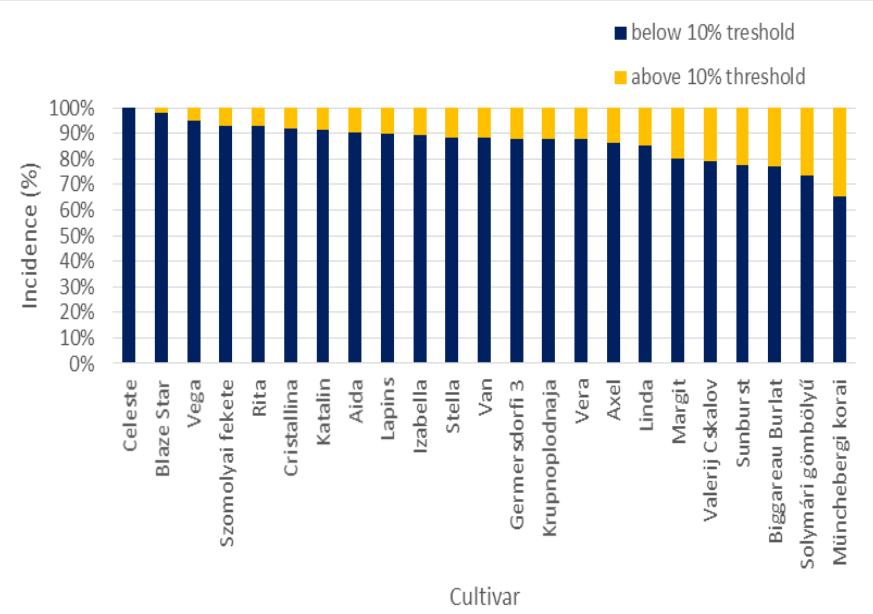

Figure 1. Overall classification of 23 sweet cherry cultivars according to the $10 \%$ disease threshold level for chery leaf spot (distributions of above and under $10 \%$ disease incidence).

Cultivar 'Münchebergi korai' exceeded extremely the 10\% threshold level. Almost all the leaves of this cultivar were diseased. Cultivars 'Biggareau burlat', 'Solymári gömbölyü' and 'Sunburst' also showed considerable diseases on the leaves.

The threshold classification of the cultivars was modified by the tree spacings (Figures 2-3). Thirteen out of the 21 cultivars had less than $10 \%$ infection in the $4 \times 1 \mathrm{~m}$ spacing (i.e. they did not reach the $10 \%$ disease threshold level). At the same time, only 3 out of the 18 cultivars showed less than $10 \%$ infection in the $5 \times 2 \mathrm{~m}$ spacing. In the more intensive cultivation of $4 \times 1 \mathrm{~m}$ spacing, the lower disease level can be explained by the fact that leaves can dry more easily in the smaller canopy of the smaller trees; therefore, leaves can not be infected so easily than on larger trees of the $5 \times 2 \mathrm{~m}$ spacing.

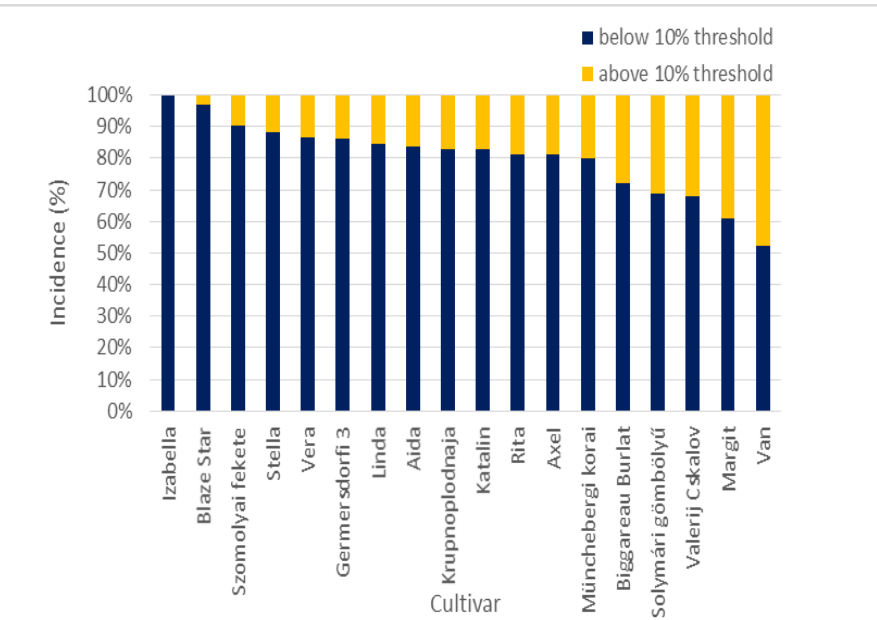

Figure 2. Classification of 18 sweet cherry cultivars for the spacing of $5 \times 2 \mathrm{~m}$ according to the $10 \%$ disease threshold level for chery leaf spot (distributions of above and under $10 \%$ disease incidence)

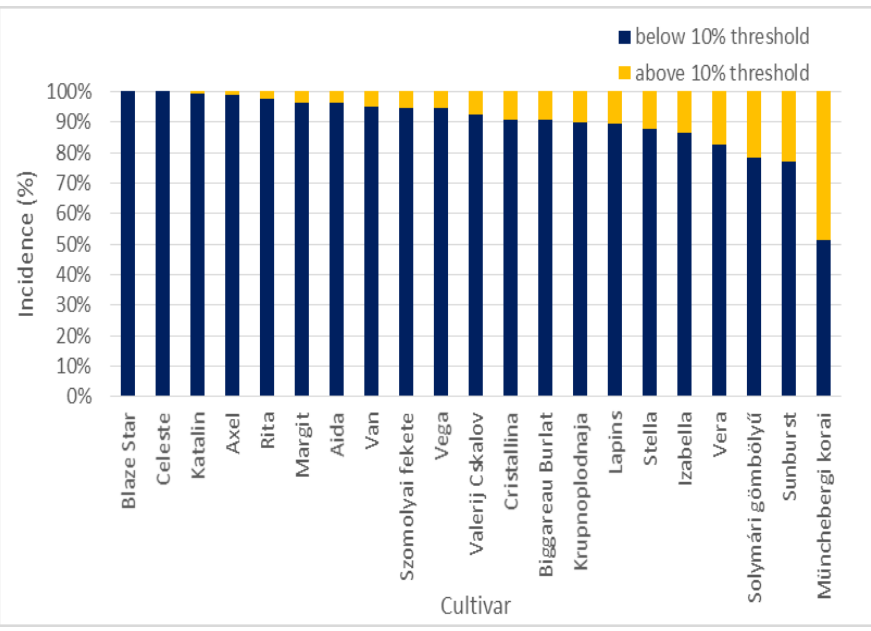

Figure 3. Classification of 21 sweet cherry cultivars for the spacing of $4 \times 1 \mathrm{~m}$ according to the $10 \%$ disease threshold level for chery leaf spot (distributions of above and under $10 \%$ disease incidence)

In the case of moderately susceptible and less susceptible cultivars, the tree spacing showed a significant difference for some cultivars e.g. 'Van' and 'Izabella'. In the case of cv 'Van', only $5 \%$ of the leaves were diseased with more than $10 \%$ disease threshold in the $4 \times 1 \mathrm{~m}$ spacing, while at the $5 \times 2 \mathrm{~m}$ spacing this value increased above $40 \%$. At the same time, cv 'Izabella' showed almost no infection in the spacing of $5 \times 2 \mathrm{~m}$, while $14 \%$ of the leaves exceeded $10 \%$ disease threshold in the $4 \times 1 \mathrm{~m}$ spacing.

\section{Conclusions}

This study proved that leaf spot incidence is affected by training system on most sweet cherry cultivars. Various effect colud be seen on moderately susceptible and less susceptible cultivars. In general, higher tree density $(4 \times 1 \mathrm{~m})$ resulted in lower cherry leaf spot incidence for most cultivars compared to lower tree density $(5 \times 2 \mathrm{~m})$ but not all cultivars follow this role.

\section{Acknowledgements}

The study was supported by the Hungarian Scientific Research Fund (K108333), by the TUDFO/51757/2019-IT Thematic Excellence Project of the University of Debrecen (Space Science Programme), by the European Union and the State of Hungary, co-financed by the European Social Fund in the framework of TÁMOP-4.2.4.A/ 2-11/1-2012-0001 'National Excellence Program' under project number A2-SZJTOK-13-0061, by the Higher Education Institutional Excellence Programme (20428-3/2018/FEKUTSTRAT) of the Ministry of Human Capacities in Hungary, within the framework of the 4th thematic programme of the University of Debrecen, and by a János Bolyai Research Fellowship awarded to I. J. Holb.

\section{References}

Borovinova, M., Christov, N., Borisova, A., Maneva, S. (2014): Evaluation of some biological properties and susceptibility to Blumeriella jaapii of sweet cherry cultivars in Kyustendil region, Bulgaria. Acta Horticulturae 1020. 131-136. https://doi.org/10.17660/ActaHortic.2014.1020.17 
Borovinova, M., Christov, N., Nyéki, J. (2007): Some biological properties of new sweet cherry cultivars in Bulgaria and their susceptibility to Blumeriella jaapii. International Journal of Horticultural Science 13(3): 95-97. https://doi.org/10.31421/IJHS/13/3/754

Borovinova, M., Petrova, V. (2015): Control of cherry leaf spot and cherry fruit fly at sour cherry. Notulae Scientia Biologia 7(2): 250-253. https://doi.org/10.15835/nsb.7.2.9618

Holb I. J., Lakatos, P., Abonyi, F. (2010): Some aspects of disease management of cherry leaf spot (Blumeriella jaapii) with special reference to pesticide use. International Journal of Horticultural Science 16(1): 45-49. https://doi.org/10.31421/IJHS/16/1/862

Holb, I., Veisz, J. (2005): A cseresznye és a meggy jelentősebb kórokozói. 138-144. In: Holb I. (ed.): A gyümölcsösök és a szőlő ökológiai növényvédelme. Mezőgazda Kiadó, Budapest, pp. 341 .

Holb, I. (2009): Some biological features of cherry leaf spot (Blumeriella jaapii) with special reference to cultivar susceptibility. International Journal of Horticultural Science 15(1-2): 91-94. https://doi.org/10.31421/IJHS/15/1-2/818

Holb, I. J., Vámos, A., Lakatos, P., Gáll, J. M., Abonyi, F. (2011): Some aspects of reduced disease management against Blumeriella jaapii in sour cherry production. International Journal of Horticultural Science 17(1-2): 49-53. https://doi.org/10.31421/IJHS/17/1-2./944

Holb, I. J., Vasileiadis, V. P., Vámos, A. (2014): Effect of sanitation treatment and cultivar on saprophytic development of Blumeriella jaapii in integrated and organic sour cherry orchards. Australas. Plant Pathol. 43. 439-446. https://doi.org/10.1007/s13313-014-0291-X

Howell, G. S., Stackhouse, S. S. (1973): The effect of defoliation time on acclimation and dehardening in tart cherry
(Prunus cerasus L.). Journal of the American Society for Horticultural Sciences 98: 132-136.

Jenser, G., Véghelyi, K. (2003): A cseresznye és a meggy növényvédelme. pp. 259-295. In: Hrotkó K. (szerk.) Cseresznye és meggy. Mezőgazda Kiadó, Budapest, p. 419.

Kaszonyi, S. (1966): Life cycle of Blumeriella jaapii infecting stone-fruit. Acta Phytopathologica Academica Scientia Hungarica, 1: 93-100.

Király, K., Szentpéteri T. (2006): Blumeriella jaapii /Rehm/ v. /Arx/ infection of some sweet cherry cultivars in two years with different precipitation conditions. International Journal of $\begin{array}{lll}\text { Horticultural } & \text { Sciences } & \text { 12(3): }\end{array}$ https://doi.org/10.31421/IJHS/12/3/655

Pedersen, H. L., Løschenkohl L. (1997): Implementation of a warning system to control cherry leaf spot (Blumeriella jaapii) under European conditions. Gartenbauwissenschaft. 62: 197201.

Proffer, T. J., Lizotte, E., Rothwell, N. L., Sundin, G. W. (2013): Evaluation of dodine, fluopyram and penthiopyrad for the management of leaf spot and powdery mildew of tart cherry, and fungicide sensitivity screening of Michigan populations of Blumeriella jaapii. Pest Management Science 69. 747-754. https://doi.org/10.1002/ps.3434

Sjulin, T. M., Jones A. L., Andersen, R. L. (1989): Expression of partial resitance to cherry leaf spot in cultivars of sweet, sour, duke, and European ground cherry. Plant Disease 73: 56-61. https://doi.org/10.1094/PD-73-0056.

Vámos, A., Holb, I. J. (2013): Cherry leaf spot incidence on 12 sweet cherry cultivars in integrated production. International Journal of Horticultural Science 19(1-2): 65-67. https://doi.org/10.31421/IJHS/19/1-2/1084 